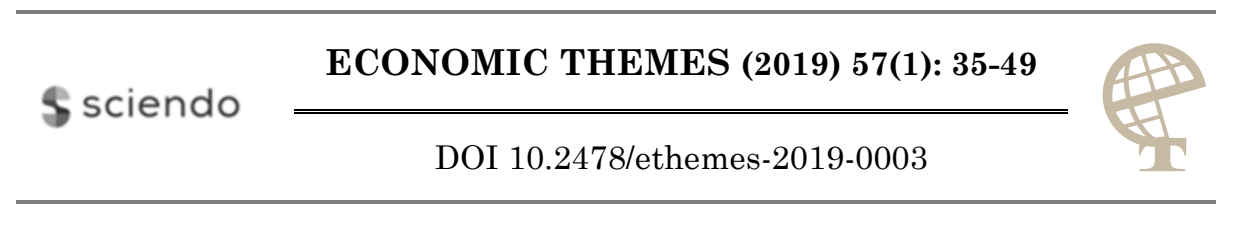

\title{
FACTORS OF THE VALUE ADDED TAX COLLECTION EFFICIENCY IN THE REPUBLIC OF SERBIA
}

\author{
Milica Ristić \\ University of Niš, Faculty of Economics, Republic of Serbia \\ $\bowtie$ milica42777@gmail.com \\ Jadranka Đurović Todorović \\ University of Niš, Faculty of Economics, Republic of Serbia \\ $\bowtie$ jadranka.djurovic@eknfak.ni.ac.rs \\ Marina Đorđević \\ University of Niš, Faculty of Economics, Republic of Serbia \\ $\square$ marina.dj@ptt.rs
}

UDC

336.226 .322

(497.11)

Review paper

Received: 02.09.2018 Accepted: 20.11.2018
Abstract: The policy led by a large number of developing countries, with the aim of increasing indirect taxes, has opened the issue of Value Added Tax (VAT) performance. Reforms of tax systems of transition countries generally involve an increase in standard rates in order to increase VAT, which is the main source of public revenues. In such a way, developing countries determine the VAT performance and the amount of revenue that could be collected by indirect taxation. Theoretical analyses of standard rates and other factors that have reflections on the VAT collection efficiency explicitly prove that there are different ways to improve the efficiency of VAT collection, and exclude an increase in the standard rate. An increase in the standard rate provides a balance of negative effects, which can be blurred by recorded tax revenues. The subject of this paper is an analysis of the factors that influence the efficiency of VAT collection in Serbia. The main objective of the paper is to examine the impact of the change in the standard rate, which is the result of the reforms carried out in 2012, on the performance of VAT. Regression analysis was applied to the data series for the period 2005-2016.The results show that the change in the standard rate had a statistically significant negative impact on VAT performance. Our analysis also indicates that the economic growth rate has reflections on VAT collection. A strong positive correlation between the economic growth rate and VAT performance was calculated.

Keywords: VAT, C-efficiency ratio, standard rate, economic growth rate, Serbia.

JEL classification: H20, H21 


\section{Introduction}

The lucrative nature of value added tax (VAT) has led to the extension of this tax and its application today in more than 150 countries. Observed in the role of providing as much public revenue as possible, its process of introduction is characteriseed as the most significant and most dramatic in tax policy in the late twentieth century (Ebrill, Keen, Bodin\& Summers, 2002).

Retrospectively, VAT appeared when the conservative approach to taxation policy did not yield the best results. Further reliance on a large number of tax rates, which were characteristic for previously applied sales tax, represented an inefficient tax policy. For this reason, and with the aim of improving macroeconomic stability, most developing countries, Serbia among them, started applying VAT in their tax systems. However, in transition countries, it was politically very difficult to use the maximum capacity of this form of tax. The reason for this is the coherence of the new tax form with the existing ones, as well as the inability to effectively charge VAT. "Value added tax is most effective when the standard rate is applied to all products and services, which enables the lowest administrative costs and no additional harmonization are required" (Đurović-Todorović\&Đorđević, 2013, p. 90), but that was not possible in transition countries.

The problem of VAT performance was dealt with by numerous theorists, and today numerous empirical research on the topic can be found, primarily due to the fact that VAT is a key component of tax systems around the world (Ebrill, Keen \& Perry, 2001) and that, in comparison with other forms of tax, this form of tax makes the biggest share of tax revenues in the state budget (Bikas\&Anduskaite, 2013 , p. 41). Increasing VAT burden is most needed in countries that cannot rely on direct taxes. According to Owens, "performance improvements can be achieved by expanding the tax base, limited use of reduced rates and exemptions, more productive tax administration and better compliance of legislation and practice" (Owens, 2011, p. 8).

Apodictically, developed countries are underpinned by administrative sophistication, for any form of taxation, which is not the case with developing countries. Increasing the productivity of the tax administration involves high costs for developing countries, which is why they avoid such a policy. However, the benefits that can be achieved by such a long-term policy can be substantially higher than the costs. Similar results were found by Ebrill and associates in their research. They consider that the basic prerequisites for efficient VAT are good design and its good implementation (Ebrill et al., 2002). "Global VAT performance depends on three main factors: structural characteristics of taxes (rates, exclusions, tax bases and the threshold of entering the tax system), the capacity of the tax administration and the level of acceptance of VAT by taxpayers" (Đurović-Todorović\&Đorđević, 2013 , p. 95). Developing countries tend to reduce the entry threshold in the tax system, although the low threshold, in several countries, is listed as one of the 
weaknesses of VAT. The empirical evidence for this conclusion is undoubtedly Ghana, a country that had a failure with introducing VAT for this reason, in 1995.

Serbia, like most developing countries, has decided to provide an increase in public revenues through "aggressive politics" by increasing the standard rate. The aim of this paper is to point out the negative reflections that the increase in the standard rate had on the efficiency of VAT collection in Serbia. Also, the paper analyses the rate of economic growth as one of the factors. By analysing the factors that influence the performance of this form of tax, we will point out the importance of the adequately defined tax policy for Serbia's economic growth and development.

\section{Literature review}

In his research, the famous economist Keen states that "even after 50 years of experience with VAT and 50 years of tendency towards a better understanding of the principles on which VAT should rest, there is so much that is unknown about this tax" (Keen, 2007, p. 18). In order to increase the volume of this form of taxation, numerous theoretical studies are supported by empirical data of the countries in which this tax is implemented.

Bogetić and Hassan (1993) examined the key determinants of VAT using statistics from 34 countries. They analysed the relationship between VAT performance and the VAT rate, tax base and determinant that represents the difference between the highest and lowest VAT rates. The analysis involved 20 countries with a single tax rate and 14 countries that applied multiple VAT rates in their tax policies. The results of their regression analysis, based on OLS techniques, confirm the impact of the tax rate and tax base on the performance of VAT. Income from value added tax increases with the expansion of the tax base. Empirical data also prove that tax revenue is higher in countries that apply a single rate than in multi-country countries. The model they received is relevant for predicting the potential of VAT in countries that are considering the introduction of a single tax rate, like Bulgaria, for example.Smith, Islam i Moniruzzaman (2011) pointed out the complexity of the VAT regime, which is difficult to administer in developed countries, and especially in developing countries, such as Bangladesh. In their work, the group of authors emphasises that Bangladesh, among other things, must conduct a policy of reducing tax rates, in order to improve VAT collection efficiency. Grandcolas (2005) empirically examined the phenomenon of value added tax in the Pacific countries which successfully implemented the VAT system. He concludes that there is a need for a strong political commitment, a detailed tax implementation plan with potential barriers, and that it is necessary to provide basic resources for the implementation of VAT, so that this tax can be successfully charged.Ebrill, Keen, Bodin and Summers (2002) observed the traditional coefficient, the C-efficiency ratio, and found the factors that were in a positive correlation with this coefficient. The results of their research bolded the 
importance of trade and GDP correlation, high literacy rate and the length of VAT application in one country. Therefore, when these factors are at a high level, Cefficiency ratio, as an indicator of VAT performance, will also be high.The results of the survey conducted by Keen (2007) shows that the standard VAT rate is a factor that can have a capital impact on the efficiency of this form of tax collection.Legeida and Sologoub (2003) observed the efficiency of fiscal policy in Ukraine. For this purpose, the authors developed the appropriate ARIMA model for forecasting VAT revenues in the short term, using the econometric method. The authors took the factors that determine the efficiency of VAT collection as a starting point for this research. The results of their research showed that VAT performance depends on the three groups of factors: the structural aspect that involves the rate and tax base of this tax, the amount of taxable activities and the taxpayers' compliance to pay taxes. Aizenman and Jinjarak (2005) analysed the efficiency of VAT collection, and saw the structural factors for the selected countries. Through panel analysis (44 countries) for the period 1970-1999, the authors proved that the efficiency of VAT collection depends on structural factors, the probability of control and penalties for unpaid tax revenues. Factors that can influence the efficiency of VAT collection are: the share of agriculture in GDP, the development of trade outside the country, as well as the level of urbanization in one country. The level of urbanization can have significant repercussions on tax revenues because, implicitly, low-level urbanization provides the possibility of easier tax evasion.

Regarding the member states of the European Union, Široký and Kovářová (2010) examined the characteristics of VAT on the example of the Czech Republic. The result of their empirical research is the impact of the VAT rate on the consumer basket, the level of prices and household expenses. Antić (2014) conducted an empirical research and comparative analysis of VAT efficiency in the countries of the European Union and Bosnia and Herzegovina. In his research, he concludes that the policy of increasing the standard VAT rate in EU Member States, without expanding the base, and with the existing structure of tax rates, would jeopardize the efficiency of VAT collection. High standard rates are deepening market disturbances and slowing the way out of the crisis. Bikas and Andruskaite (2013) also examined other factors that have a significant effect on VAT revenue in the countries of the European Union. For this purpose, they took the data in the period from 2004 to 2011 and applied the model of multiple regression. Their results show that there is a high level of correlation between the analyzed factors relevant for VAT calculation and VAT revenues. The macroeconomic factors that the authors included in the model were: gross domestic product, gross domestic product per capita, unemployment, consumption, household consumption, government spending, exports and imports in EU member states. This research also suggests that governments focus on fiscal policy reform. 
VAT revenues depend on a large number of factors. VAT is particularly sensitive to the rate of growth and changes in domestic demand. Exports are usually the result of increased production, and can result in an increase in domestic demand. Imports will, explicitly, have different repercussions. An increase in imports in one country will result in an increase in tax revenues (Haybka, 2009).

Numerous empirical studies have found that there is a negative correlation between the standard VAT rate and the efficiency of its collection. Economists agree on the view that high tax rates cannot provide the required collection efficiency of any form of taxation. This claim is theoretically corroborated by Owens (2011), pointing out that, although the increase in the standard rate is considered the easiest way to reduce budget deficits, an increased standard rate can jeopardize VAT performance. The growth of the standard rate is accompanied by a number of exemptions which, together with the reduced rates, can limit the growth of tax revenues, VAT taxes in Serbia are very plentiful source of income, but they additionally burden the poor citizens. Any new increase in the VAT rate and excise must be based on a detailed analysis of the economic and social situation in the country“ (Janković-Milić \& Đurović-Todorović, 2017, p. 284).,,The revenue from consumption taxes (indirect taxes) are the most abundant revenue group in tax systems“(Đorđević, 2014, p. 1155).

Đorđević (2014) pointed out the impossibility of increasing revenue from consumption taxes and examined alternative ways of providing revenue to reduce deficit in the budget of Serbia. Improving the efficiency of VAT collection can be achieved by expanding the tax base and by the limited use of reduced rates. Analogously, more efficient tax administration can have positive reflections on VAT performance.

\section{VAT collection efficiency in Serbia and identification of factors affecting C-efficiency ratio}

\subsection{The econometric metodology and data}

The fact is that all developing countries have taken significant efforts in developing and reconstructing their tax systems. In order to reduce and mitigate the effects of the crisis, the Serbian government has accessed the cheapest, but at the same time the most aggressive policy, an increase of the standard VAT rate. For economic objectification and definition of this policy as ineffective, a certain period of its application was required. Tax policy defects, therefore, could not be seen immediately, and an increase in VAT revenues was evident.

The capcious questions imposed on economists are: Has the increased standard VAT rate affected the growth rate of this tax? Are the performances of VAT, which has existed Serbia for 12 years, satisfactory? Has the tax system become more efficient with the increased standard rate? 
A good "tax portfolio" can be of inherent importance for Serbia's economic growth and development. The amount of money collected from indirect taxes should compensate for the amount of money which the developing country is unable to collect from direct taxes. On the other hand, a good tax system affects the behaviour of market participants because taxes will be collected depending on the tax rates that have been provisioned for all forms of taxation, the law, which should substantiate the taxation, the principles that must be met and the effective tax control.

Figure 1. Factors that influence the taxpayers' compliance

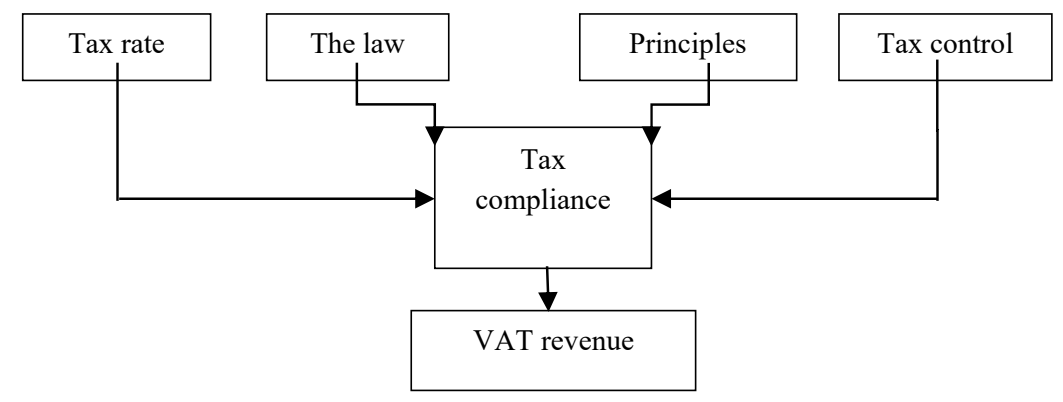

Source: Authors, based on research carried out in BiH (Grgić, Terzić, 2014, 962)

Table 1. Structure of VAT in Serbia (in \%), 2005-2017.

\begin{tabular}{|c|r|r|r|l|}
\hline \multirow{2}{*}{ VAT rates } & \multicolumn{3}{|c|}{ Period of application rate } & \multirow{2}{*}{ Goods and services } \\
\cline { 2 - 4 } & $2005-2012$. & $2012-2014$. & $2014-2017$. & \\
\hline $\begin{array}{c}\text { Reduced } \\
\text { rate }\end{array}$ & $8 \%$ & $8 \%$ & $10 \%$ & $\begin{array}{l}\text { Basic groceries communal } \\
\text { services; accommodation in } \\
\text { tourism; cultural events; } \\
\text { daily newspapers; } \\
\text { agricultural stocks; } \\
\text { textbooks and teaching aids. }\end{array}$ \\
\hline $\begin{array}{c}\text { Standard } \\
\text { rate }\end{array}$ & $18 \%$ & $20 \%$ & $20 \%$ & $\begin{array}{l}\text { All other taxable goods and } \\
\text { services. }\end{array}$ \\
\hline & $0 \%$ & $0 \%$ & $0 \%$ & $\begin{array}{l}\text { Export and related transport } \\
\text { services. }\end{array}$ \\
\hline
\end{tabular}

Source: International VAT and GST rates, 2018.http://www.vatlive.com/vat-rates/ international-vat-and-gst-rates/.

Table 1 shows the structure of VAT rates in Serbia. Serbia introduced the increase in the standard tax rate (Law on Amendments and Supplements to the Law on Value Added Tax, 2012, Article 15, p. 25). In the observed period, 2005-2016, 
there was an increase in total tax and VAT revenues. However, the growth rate of VAT revenue was reduced.

Graph 1. Rate of growth of VAT revenues in Serbia (in \%), 2005-2016

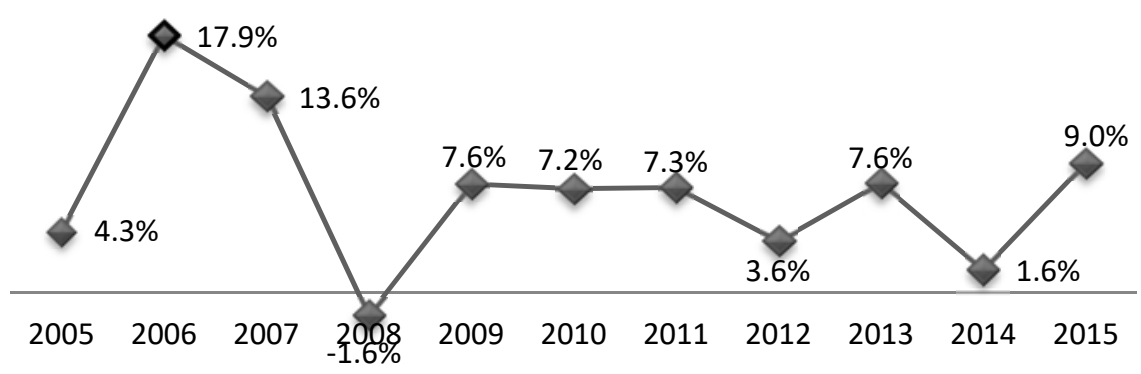

Source: Ministry of Finance RS. Bulletin of public finances, 2017.Authors' calculations

Graph 1 shows that, in the year of the tax rate increase, 2012, the rate of growth of VAT revenues was lower by $3.7 \%$ compared to the previous year. Analogously, the same reflection of the tax rate reduction can be seen in 2014, when the reduced VAT rate increased from $8 \%$ to $10 \%$.We will get the answers to the questions: whether the VAT performance is satisfactory and whether the tax system became more efficient after the rate change, on the basis of the relevant VAT performance indicator, C-efficiency ratio. According to the IMF methodology, applied by OECD member countries, C-efficiency ratio can be calculated on the basis of the following formula (Keen, 2013, p. 427; Ueda, 2017, p. 8):

$$
E^{C} \equiv \frac{V}{P V^{T}}
$$

Where,

$$
P V^{T}=\tau^{S}(F C-V)
$$

Where: $\mathrm{V}$ is realised VAT revenue, $P V^{T}$ is VAT revenue that can be realised, theoretical arrival, $\tau^{S}$ is standard rate, and FC is final consumtion.

Numerous empirical studies have shown that the coefficient never has a value of 1 , although the approximation to number 1 represents an ideal value and an ideal tax policy. Here, the lack of this ratio is noticeable, because its precision is greatest in the case when the country applies only one standard rate, without any exceptions.

In the observed time zone, the C-efficiency ratio of VAT shows the continuity of the fall. 
Graph 2. C-efficiency ratio of VAT in Serbia (in \%), 2005-2016.

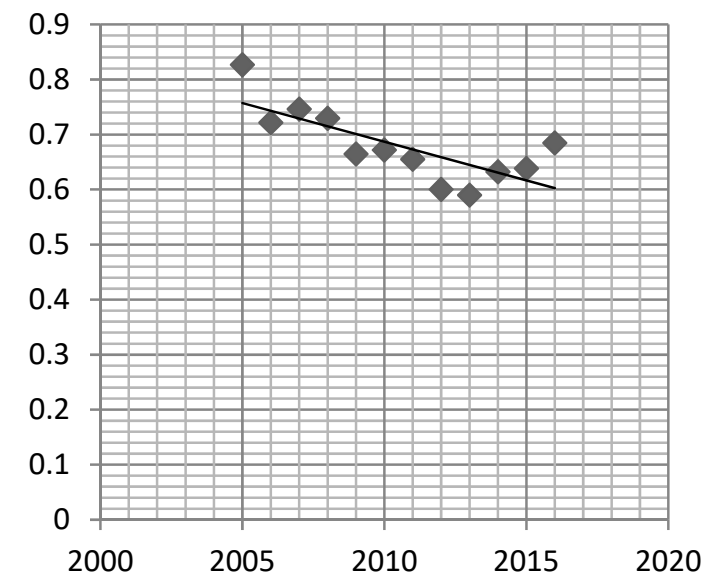

Source: Statistical Office of the Republic of Serbia, 2011; Ministry of Finance RS, Bullitin of Public Finance, 2017. Autors' calculation.

C-efficiency ratio, which is assessed as a relevant coefficient for measuring the performance of VAT, is shown in Graph 2. The Ratio indicates that there is a gap between the actually collected revenues and the revenues that could actually be collected. The performance is unsatisfactory especially in the years that followed the increase of the standard tax rate. To compare the mean value of C-efficiency ratio in the periods with the standard rate $18 \%$ and the periods when it was $20 \%$, the Independent-Samples T-Test will be used.

Table 2. T-Test results, the period 2005-2016.

\begin{tabular}{|l|c|c|c|c|}
\cline { 2 - 5 } \multicolumn{1}{c|}{} & Standard rate & Mean & Std.Deviation & Sig. \\
\hline \multirow{2}{*}{$\begin{array}{l}\text { C-efficiency } \\
\text { ratio }\end{array}$} & $2005-2012$. & .7165 & .06011 & .335 \\
\cline { 2 - 5 } & $2012-2016$. & .6290 & .03720 & \\
\hline
\end{tabular}

Source: Authors.

Based on the results of the T-test, shown in Table 2, it can be concluded that there is significant difference in C-efficiency values between the period with the rate $18 \%(\mathrm{M}=0.7165, \mathrm{SD}=0.06011)$ and the period with the rate $20 \%(\mathrm{M}=0.6290$, $\mathrm{SD}=0.03720)$.

Clearly, improving administration, labour efficiency, reducing the number of rates and similar reforms represent a "costly" policy for transition countries, while increasing the tax rate is part of a policy that is in line with the level of their development. However, if the defects of such policy are greater than its positive effects, why are they preferred by so many governments? 
Indirect taxes are inherently important for Serbia. Only on the basis of these taxes, Serbia collects on average $46 \%$ of tax revenues, where the share of VAT is, on average, $29 \%$ (2005-2016). A healthy economic field and conditions for economic growth and development can be created in Serbia by eliminating the effects of all the factors that negatively affect or do not affect the performance of this tax at all. The share of VAT revenues in Serbia's GDP was the least in the year of the October reform. VAT revenues amounted to $9.8 \%$ of GDP (2012), which is by $2.5 \%$ less compared to the efficiency achieved in the year of its introduction into Serbian tax system (2005).

The subject of this research are two factors which we consider to have the greatest impact on the efficiency of VAT collection. The basic aim of the paper is to examine the interdependence between the standard rate and the performance of VAT. Analogously, the correlation between the rate of economic growth (GDP, real growth, in \%) and VAT performance will be established. We opted for the analysis of the rate of economic growth, on the assumption that the growth of the rate of economic growth increases export, and the increase in export can have negative effects on the collection of taxes. Also, the rate of economic growth is in a negative correlation with household consumption.

We will use the following databases: the Central Bank of Serbia, the Ministry of Finance and the Republic Institute for Statistics.

\subsection{The econometric results}

The direction and strength of the linear relationship between the variables will be determined by correlation analysis. C-efficiency ratio will be used as an indicator of VAT performance in Serbia. The standard VAT rate will be presented as a dummy variable, i.e. with the help of a dummy variable (indicator variable, construction variable). Dummy variable will allow us to see the reflection of the standard rate change to the tax policy of Serbia. The variables will be observed in the period of 2005-2016.

The results of the correlation analysis are shown in Table 3. Based on Pearson's correlation coefficient, the authors conclude that there is a strong negative correlation between C-efficiency ratio and the standard rate, which is statistically significant $(\mathrm{r}=$ $-0.672, p<0.05$ ). Therefore, based on the results, it can be concluded that the change in the standard VAT rate negatively affects the VAT performance. The coefficient of determination, which shows the extent to which the variance of one variable is caused by the variance of the other, for C-efficiency ratio and the standard rate, is $45 \%$. Accordingly, the change in VAT standard rate explains $45 \%$ of C-efficiency ratio variance. A strong positive correlation between $\mathrm{C}$-efficiency ratio and the economic growth rate $(\mathrm{r}=0.707, \mathrm{p}<0.05)$ was calculated. The coefficient of determination for these two variables is $49 \%$, with the economic growth rate explaining $49 \%$ of C-efficiency variance. Based on the correlation coefficient, the high level of C-efficiency involves a high level of economic growth rate. 
Table 3. Correlation coefficients

\begin{tabular}{|c|l|c|c|c|}
\hline \multicolumn{2}{|c|}{} & C-efficiency ratio & $\begin{array}{c}\text { Economic growth } \\
\text { rate }\end{array}$ & Standard rate \\
\hline \multirow{2}{*}{$\begin{array}{c}\text { C-efficiency } \\
\text { ratio }\end{array}$} & $\begin{array}{l}\text { Pearson } \\
\text { Correlation }\end{array}$ & 1 & $.707^{*}$ & $-.672^{*}$ \\
\cline { 2 - 5 } & Sig. (2-tailed) & & .010 & .017 \\
\hline \multirow{2}{*}{$\begin{array}{c}\text { Economic } \\
\text { growth rate }\end{array}$} & $\begin{array}{l}\text { Pearson } \\
\text { Correlation }\end{array}$ & $.707^{*}$ & 1 & -.383 \\
\cline { 2 - 5 } & Sig. (2-tailed) & .010 & & .219 \\
\hline \multirow{2}{*}{ Standard rate } & $\begin{array}{l}\text { Pearson } \\
\text { Correlation }\end{array}$ & $-.672^{*}$ & -.383 & 1 \\
\cline { 2 - 5 } & Sig. (2-tailed) & .017 & .219 & \\
\hline
\end{tabular}

Note:* Correlation is significant at the 0.05 level (2-tailed).

Source: Authors.

According to the fact that the correlation analysis pointed out the existence of strong and significant connections, Table 3 shows the results of the regression analysis. Preliminary analyses proved that the assumptions of variance multicollinearity were impaired. This conclusion is supported by the value of VIF, 1.172 , which is much below the average value, which is 10 . The multiple regression model examines the impact of the analysed factors, standard rates and economic growth rates, which are independent variables, on VAT performances, i.e., C-efficiency ratio, which is the dependent variable.

Table 4. Estimated regression coefficients

\begin{tabular}{|c|c|c|c|c|c|}
\hline & \multicolumn{2}{|c|}{ Unstandardized Coefficients } & \multicolumn{2}{c|}{$\begin{array}{c}\text { Standardized } \\
\text { Coefficients }\end{array}$} & \\
\cline { 2 - 4 } & $\mathrm{B}$ & Std. Error & Beta & $\mathrm{t}$ & Sig. \\
\hline \begin{tabular}{c} 
(Constant) \\
\hline $\begin{array}{c}\text { Economic } \\
\text { growth rate } \\
(\text { EGR) }\end{array}$
\end{tabular} & .682 & .020 & & 33.393 & .000 \\
\hline $\begin{array}{c}\text { Standard } \\
\text { rate (SR) }\end{array}$ & -.061 & .004 & .527 & 2.612 & .028 \\
\hline
\end{tabular}

*Dependent variable: C-efficiency ratio

Source: Authors

The estimated values in the regression model shown in Table 4, can be represented in the following equation: 


$$
\text { C efficiency ratio }=0.682+0.012 \cdot E G R-0.061 \cdot S R
$$

The results of the evaluated model show that the two independent variables in the model statistically significantly influence the dependent variable. The unique contribution of the standard rate in the explanation of the dependent variable is statistically significant $(p=0,045)$. The unique contribution of the economic growth rate to the prediction of the dependent variable is also statistically significant $(\mathrm{p}=0,028)$. Increasing the economic growth rate by $1 \%$ causes an average increase in C-efficiency by $1,2 \%$, while an increase of the standard rate causes an average reduction in C-efficiency by $6,1 \%$. This model explains $68.8 \%$ of the total Cefficiency variance. The regression model has statistically significant prediction power $(\mathrm{p}=0,005)$.

In accordance with the results of the model, the analysed factors, the significance of which we have bolded, are of importance for increasing the efficiency of VAT collection in Serbia. Implicitly, there are other factors that can influence the performance of VAT, which we did not include in the analysis. We can conclude that the increase in the standard rate, from $18 \%$ to $20 \%$, had negative reflections on the VAT performance, and that it was one of the factors of the continuous decline in C-efficiency in the observed period. On the other hand, the rate of economic growth has positive reflections on the rational-C efficiency, that is, the growth of the rate means the increase in the efficiency of VAT collection.

Graph 3. Movement of factors that influence the C-efficiency ratio (in \%), 2005-2016.

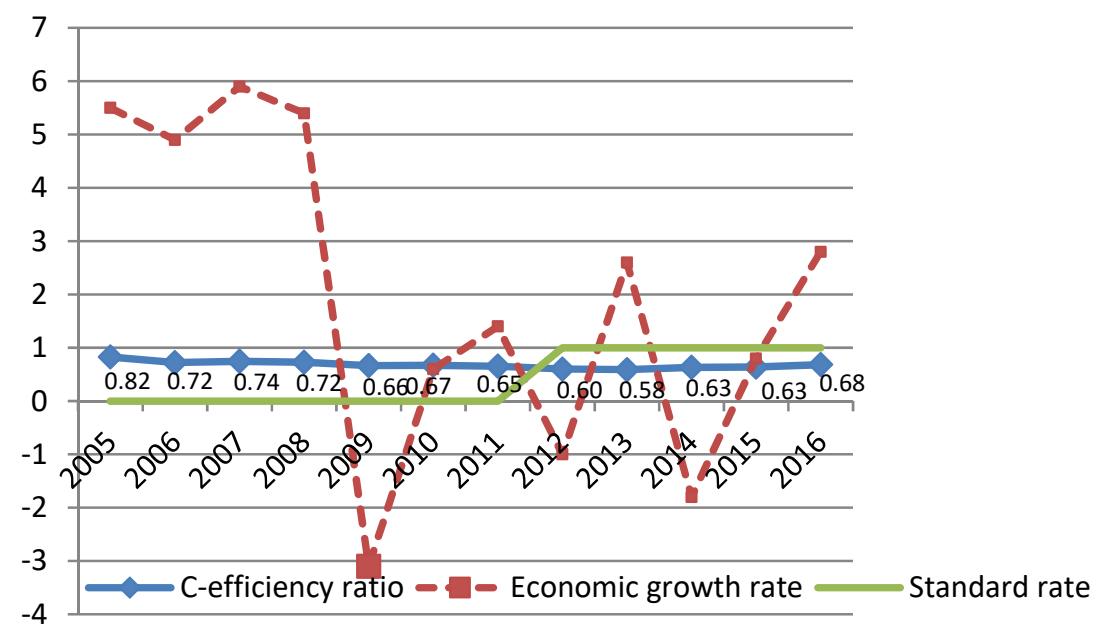

Source: The Republic Institute for Statistics, National Bank of RS, Ministry of Finance RS. Authors' calculations. 
Graph 3 shows the movement of the observed variables values in the period 2005-2016. It can be seen that cyclical developments in the rate of economic growth, as well as the change in the standard rate, affect the performance of VAT in accordance with the model obtained.

\section{Conclusion}

The paper indicates the imperfection of inadequately defined VAT rates on Serbia's economic growth and development, and explicitly calls into question the tax policy of the government. Since the legal regulation of this tax by the European Economic Community, in 1970, most countries faced a capricious issue, the upper limit of the standard rate. The authors, Legeida and Sologob find the reason for the existence of lower tax rates in the problem of the taxpayers' compliance to pay the tax, as well as in the prescribed exceptions. They consider that "the effective tax rate is lower than the statutory tax rate" (Legeida, Sologoub, 2003, 6). On the other hand, the universal tax rate, which can be instrumentalised in the tax systems of all developing countries, does not exist. The most important determinant for determining the tax rate in one country is the time period of application of the specific tax form. The lower tax rate (18\%), which existed in Serbia, had a higher collection efficiency and a higher VAT rate. What is more, the state should not practise the frequent changes in tax rates. A frequent change in the standard rate cannot result in satisfactory public revenue. An example for this policy is Romania, which, by frequent change in the standard rate, had a negative impact on the efficiency of VAT collection.

The aim of this paper was to point out the factors influencing the efficiency of the tax system, not only in Serbia, but also in other developing countries. Based on the high correlation (negative) between the change in the standard rate and Cefficiency rate, it can be concluded that the reduction in the rate would have a positive reflection on VAT revenues. A high tax rate in Serbia cannot have positive repercussions on VAT performance. One of the reasons for this is the legal system in Serbia. VAT efficiency is related to the scope of the tax law that makes the legal apparatus too bulky. Extensive legislation prevents tax authorities from working efficiently. On the other hand, a high standard rate, as well as a multitude of prescribed exemptions, allow VAT payment evasions. A high tax rate, therefore, can only reduce the taxpayers' compliance to pay taxes. Analogously, VAT has its reflections on goods and services that are reflected in the balance of everyday necessities, and this ultimately reduces household spending.

The highest efficiency of VAT collection is possible if fiscal policy measures are correlated with economic and structural policies and have a strong synergetic effect. A clearly defined policy can improve the development and competitiveness of a country. 


\section{References}

Aizenman J. \& Jinjarak Y. (2005). The Collection Efficiency of the Value Added Tax: Theory and International Evidence, NBER Working Paper No. 11539, National Bureau of Economic Research. doi: 10.3386/w11539.

Andrejovská, A. \& Mihóková, L. (2015), Developments of VAT Rates in EU Countries in the Context of Harmonization and Fiscal Consolidation. Acta Universitatis Agriculturae et Silviculturae Mendelianae Brunensis, 63(2), 487-498.

Antić, D. (2014). Efficiency of a single-rate and broad-based VAT system: the case of Bosnia and Herzegovina. Financial Theory and Practice, 38(3), 303-335.

AvalaraVATlive, International VAT and GST rates, 2018. http://www.vatlive.com/vatrates/international-vat-and-gst-rates/.

Bikas, E.\& Andruskaite E. (2013). Factors affecting Value Added Tax Revenue.European Scientific Journal, European Scientific Institute.

Bird, R. (1987). A New Look at Indirect Taxation in Developing Countries. Pergamon Journals, $15(9), 1151-1161$.

Bogetic, Ž. \& Hassan, F. (1993). Determinants of value - added tax revenue: a cross section analysis. Policy, Research working papers No. WPS 1203.Country operations. Washington: The World Bank.

Clément, C. (2007). Who pays sales taxes? Evidence from French VAT reforms, 19871999.Journal of Public Economics, 91(5-6), 1219-1229.

Đorđević, M. (2014). (Im)Possibilities of revenue increase from consumption taxes in the tax sistem of Serbia. Themes - Journal for social sciences. 3 (2014), 1155-1171.

Đurović-Todorović, J. \& Đorđević, M. (2013). Porezi na potrošnju, Niš: Ekonomski fakultet.

Ebrill, L., Keen, M. \& Perry, V. (2001). The Modern VAT. Washington: International Monetary Fund.

Ebrill, L., Keen, M., Bodin, J. P. \&Summers, V. (2002). The Allure of the Value-Added Tax, Finance \& Development, A quarterly magazine of the IMF, 39(2).

Grandcolas, Ch. (2005). The Occasional Failure in VAT Implementation: Lessons for the Pacific. Asia-Pacific Tax Bulletin. http:/unpan1.un.org/intradoc/groups/public/ documents/ unpan/unpan019991.pdf.

Grgić, R. \& Terzić, S. (2014). Tax evasion in Bosnia and Hercegovina and business environment.Procidia-Social and Behavioral Sciences, 119 (2014), 957-966.

Hillman, A. (2009). Public Finance and Public Policy, Responsabilities and Limitations of Government. Second Eddition, Cambridge: University press.

Hybka, M.M. (2009). VAT Collection Efficiency in Poland before and after Accession to the European Union-a, .Ekonomika, 85(2009): 7-18.

Janković-Milić, V. \& Đurović-Todorović, J. (2017). Regressivity of Value Added Tax in the European Union and the Republic of Serbia. Improving micro and macro competitivenessproblems and possible solutions (267-285). Niš: Faculty of economics.

Jenkins, G. P. (2000). A VAT Revenue Simulation Model for Tax Reform in Developing Countries. Cambridge: Harvard Institute for International Development, 28 (4), 763-774.

Keen, M. \& Lockwood B. (2006). Is the VAT a Money Machine?.National Tax Journal, 59(4), 905-28.

Keen, M. (2007). VAT Attacks!, IMF Working Papir!, WP/07/142. Washington: International Monetary Fund.

Keen, M. (2013). The Anatomy of VAT.IMF Working Papir WP/13/111. Washington: Internatinal Monetary Fund.

Khadem, N. (2017). Nobel-prize winning economist Joseph Stiglitz on how to stop inequality and tax avoidance. The Sydney Morning Herald, http:/www.smh.com.au/business/the- 
economy/nobelprize-winning-economist-joseph-stiglitz-on-how-to-stop-inequality-and-taxavoidance-20170914-gyhnmh.html .

Law on Amendments and Supplements to the Law on Value Added Tax, Official Gazette of RS, no. 93/2012.

Legeida, N. \& Sologoub, D. (2003). Modeling Value Added Tax (VAT) Revenues in a Transition Economy: Case of Ukraine, 1-21. Institute for economic research and policy consulting working paper No. 22.

Ministry of Finance RS, Bullitin of Public Finance. No. 156 (2017).

National Bank of RS, Basic macroeconomic indicators (2017). https://www.nbs.rs/internet/ cirilica/80/index.

Owens, J. (2011). Improving performance of VAT system is a priority in the context of the economic crisis. World Commerce Review, 5(3), 8-10.

Popa, M. (2014). Taxes, Fees and Obligations in Romania - Main Components of Companies's Fiscal Costs, Procidia - Social and Behavioral Sciences, 109(2014), 150-154.

Smith, A., Islam, A. \& Moniruzzaman M. (2011). Consumption Taxes in Developing Countries The Case of the Bangladesh VAT, Working Paper Series, Working Paper No. 82.

Široký, J. \& Kovářová, A. (2010), The Causes of Changes in the Rates of Value Added Tax in the Czech Republic and their Possible Impacts. Acta všfs, 4(2), 121-134.

The Republic Institute for Statistics, Use of the gross domestic product of the Republic of Serbia,1995-2016.http://www.stat.gov.rs/WebSite/Public/PageView.aspx?pKey=62.

Ueda, J. (2017). The Evolution of Potential VAT Revenues and C-Efficiency in Advanced Economies.IMF Working Paper WP/17/158. Washington: International Monetary Fund.

\section{FAKTORI EFIKASNOSTI NAPLATE POREZA NA DODATU VREDNOST U REPUBLICI SRBIJI}

Apstrakt: Politika koju vodi veliki broj zemalja u razvoju, u cilju povećanja indirektnih poreza, otvorila je pitanje izučavanja performansi poreza na dodatu vrednost (PDV). Reforme poreskih sistema zemalja u tranziciji, uglavnom, involviraju povećanje standardnih stopa u cilju povećanja PDV-a, koji je osnovni izvor njihovih javnih prihoda. Na takav način, zemlje u razvoju determinišu performanse PDV-a i iznos prihoda koji bi mogao biti naplaćen indirektnim oporezivanjem. Teorijske analize standardne stope i ostalih faktora, koji imaju refleksije na efikasnost naplate PDV-a, eksplicitno dokazuju da postoje različiti načini za poboljšanje efikasnosti naplate PDV-a, i isključuju povećanje standardne stope. Povećanje standardne stope pruža bilans negativnih efekata, koji mogu biti zamagljeni evidentiranim poreskim prihodima. Predmet istraživanja ovog rada je analiza faktora koji utiču na efikasnost naplate PDV-a u Srbiji. Osnovni cilj rada je da ispita uticaj promene standardne stope, koja je rezultat reformi sprovedenih 2012. godine, na performanse PDV-a. Primenjena je regresiona analiza na seriju podataka za period 2005-2016. Rezultati pokazuju da je promena standardne stope imala statistički značajan negativan uticaj na performanse PDV-a. Naše analize, takođe, indiciraju da stopa privrdnog rasta ima refleksije na naplatu PDV-a. Izračunata je jaka pozitivna korelacija između stope privrednog rasta i performansi PDV-a.

Ključne reči: PDV, racio C-efikasnosti, standardna stopa, stopa privrednog rasta, Srbija. 


\section{Authors' biographies}

Jadranka Đurović Todorović has been Full Professor at the Faculty of Economics, University of Niš since 2012. Her fields of interest are monetary economics and public finance. She teaches at all three levels of study. She is a winner of the Silver Sign of University of Niš, as the best graduate student in 1992 and and the October Award of the City of Leskovac for Finance in 2015. She is a reviewer in numerous journals and an author of 4 books and 3 monographs. She has been a participant of many domestic and international projects in field of economics and she is the author of more than 140 scientific articles published in domestic and international journals and thematic collections of papers from international and domestic scientific conferences.

Marina Đordevic is Associate Professor at the Faculty of Economics, University of Niš. She teaches Monetary and Public Finance. She earned her Master's degree and doctorate degree from the Faculty of Economics in Niš in 2002 and 2009, respectively. She has published a number of papers in scientific journals and has participated in national and international conferences in the country and abroad. She has participated in projects of the Faculty of Economics in Nis and the Ministry of Science, Republic of Serbia.

Milica Ristić received the BSc and MSc degrees in economics from the Faculty of Economics, University of Niš, Serbia in 2015 and 2016, respectively. Milica is currently a $\mathrm{PhD}$ student conducting research in the field of public finance. She works as a demonstrator at the Faculty of Economics, University of Niš. She has a member of various project teams that developed feasibility studies, business plans, unemployment analysis and so forth. Her field of research includes public finance, taxation, fiscal policy, shadow economy, financial reporting and banking. She is the (co)author of several scientific papers related to the abovementioned topics. She participated in the research of Russian state budget at the Belgorod State Technological University, V.G.Shukhov in Russia. She is a scholar of the Ministry of Education, Science and Technological Development. 